\title{
EVALUASI TEKNOLOGI AIR MINUM ISI ULANG DI DKI JAKARTA
}

\author{
Oleh : \\ Satmoko Yudo dan P. Nugro Rahardjo \\ Kelompok Teknologi Pengelolaan Air Bersih dan Limbah Cair, Pusat Pengkajian dan Penerapan \\ Teknologi Lingkungan - BPPT
}

\begin{abstract}
Nowadays raw water resources for drinking water are less and less available, especially in Jakarta. For example, the condition of most rivers in Jakarta is extremely polluted by wastewaters, such as domestic and industrial wastewater. Some of industrial wastewater straightly discharged into the rivers are classified as toxic and hazardous wastewater. Therefore all rivers in Jakarta are not feasible to be used as the raw water for clean water treatment processes. Even ground water is not already safe to be used as the raw water for drinking water, because it has commonly been contaminated by seepage of septic tanks and polluted surface waters. Because of that, many people living in Jakarta tried to find other alternatives. Commercially sold mineral water is one good option for supplying drinking water need, but the prices are relatively expensive for most of people.

There were more than 1,000 refill drinking water depots growing in the last ten years. They are one of the best answers to many people, but the quality of drinking water is still debatable. In other word, there is not a standard regulation for the water treatment processes, so the depots cannot guarantee that the produced water already fulfill the quality standard of drinking water. In order to give a good service for community living in Jakarta, it is very important to evaluate all aspects of technology, management and services.
\end{abstract}

Keywords : Refill drinking water technology, water treatment processes.

\section{PENDAHULUAN}

\section{$1.1 \quad$ Latar Belakang}

Laju pertumbuhan penduduk yang cukup tinggi setiap tahun serta percepatan perkembangan pembangunan yang terjadi di Propinsi DKI Jakarta menyebabkan peningkatan kebutuhan pelayanan infrastruktur yang sangat besar termasuk pelayanan air minum. Untuk mempercepat peningkatan pelayanan air minum memerlukan dana yang tidak sedikit, sedangkan kemampuan Perusahan Air Minum sangat terbatas. Sementara jumlah air tanah sekarang ini sangat terbatas, kondisi demikian tidak memungkinkan penggunaan air tanah sebagai sumber air baku andalan untuk keperluan air minum masyarakat Jakarta. Selain itu juga kualitas air tanah diketahui telah tercemar oleh E. Coli yang berasal dari buangan atau limbah rumah tangga ${ }^{(1)}$.

Upaya yang telah dilakukan Pemerintah DKI Jakarta untuk penanggulangan masalah tersebut selama ini adalah dengan membangun 11 (sebelas) percontohan unit penyediaan air minum isi ulang yang sudah dioperasikan dan ratusan unit lainnya yang dipasang oleh masyarakat sendiri sebagai suatu kegiatan usaha dalam rangka memenuhi kebutuhan/permintaan masyarakat akan air minum.

\subsection{Permasalahan}

Sejak awal tahun 1998 sampai saat ini usaha air minum isi ulang terus berkembang pesat, selain hanya membutuhkan investasi yang relatif murah antara 20-70 juta, dan juga air hasil olahannyapun layak diminum karena sumber air bakunya dari pegunungan, serta harga jual air yang terjangkau, yaitu sepertiga dari harga jual air kemasan atau air mineral yang bermerk.

Namun dengan maraknya isu terjadinya pencemaran air minum isi ulang oleh bakteri serta belum adanya standardisasi yang baku dalam pemrosesan air minum isi ulang, maka dipandang perlu untuk melakukan evaluasi secara menyeluruh terhadap teknologi yang digunakan dalam memproduksi air minum isi ulang, maupun terhadap kualitas air yang dihasilkan guna memberi jaminan perlindungan dan kepercayaan masyarakat sebagai pemakai air minum isi ulang tersebut.

\subsection{Tujuan}

Tujuan kajian ini adalah untuk melakukan evaluasi terhadap teknologi proses air minum isi 
ulang yang sudah tersebar secara luas untuk mengetahui apakah teknologi yang digunakan telah memenuhi proses pengolahan untuk air minum, serta mengetahui kendala-kendala yang dihadapi dalam operasionalnya dan mencari solusi pemecahan masalah agar hasil air olahannya menjadi lebih baik di masa yang akan datang.

\subsection{Manfaat}

Manfaat yang diharapkan dari kegiatan ini adalah tersedianya standar teknologi untuk proses produksi air minum isi ulang yang berkualitas, agar dapat dikonsumsi masyarakat dan timbulnya kepercayaan masyarakat terhadap produk air minum isi ulang.

\section{METODOLOGI}

\subsection{Tahap Persiapan}

Langkah awal dalam setiap kegiatan penelitian adalah persiapan. Pada tahap persiapan ini disusun rencana dan urutan kegiatan. Rencananya, batas wilayah obyek lokasi kegiatan ini adalah 5 wilayah Jakarta, yaitu Jakarta Pusat, Jakarta Utara, Jakarta Timur, Jakarta Barat dan Jakarta Selatan. Langkah berikutnya adalah pelaksanaan survey lapangan, yaitu melakukan observasi lapangan yang meliputi pemilihan lokasi sampling di wilayah yang mempunyai depot air minum isi ulang. Jumlah depot isi ulang yang akan dievaluasi meliputi 10 depot yang terdiri dari 2 lokasi di setiap wilayah (lihat Tabel 1). Gambaran yang diperoleh dari hasil observasi lapangan digunakan untuk mengevaluasi sistem teknologi proses pengolahan air yang digunakan.

\subsection{Tahap Survey Lapangan}

Sesuai dengan yang telah direncanakan bahwa survey lapangan meliputi pengambilan data tentang sistem pengelolaan depot isi ulang dan tentang kondisi sosial-ekonomi masyarakat pengguna serta pengambilan sampel air hasil olahan depot isi ulang.

Pengumpulan data dilakukan dengan melaksanakan wawancara terhadap pemilik atau pengusaha depot air isi ulang dan masyarakat disekitarnya. Wawancara berdasarkan pertanyaan-pertanyaan yang disusun dalam sebuah kumpulan kuesioner. Kuesioner evaluasi terdiri dari dua topik pertanyaan, yaitu pertanyaan kondisi alat dan pengelola alat, serta kondisi sosial-ekonomi masyarakat. Evaluasi kondisi fisik dan teknis peralatan meliputi kapasitas alat, spesifikasi, proses pengolahan, kondisi peralatan dan biaya operasional serta permasalahan yang ada saat ini. Evaluasi kondisi sosial-ekonomi ditujukan kepada beberapa masyarakat di sekitar lokasi depot untuk mengetahui tingkat sosial-ekonomi, serta presepsi masyarakat setempat terhadap air minum isi ulang tersebut.

Kemudian dilakukan pengambilan sampel air hasil olahan untuk melihat kualitas hasil pengolahan air minum isi ulang.

\subsection{Tahap Pengolahan dan Analisa Data}

Hasil pengumpulan data kuesioner yang diperoleh dari observasi lapangan kemudian diolah dengan bantuan program komputer dan hasilnya kemudian dianalisa. Sedangkan hasil pengambilan sampel air hasil olahan dianalisa di laboratorium dan hasilnya dibandingkan dengan standar baku mutu air minum.

\section{HASIL KEGIATAN}

\subsection{Proses dan Teknologi Pengolahan Air}

Proses pengolahan air minum pada intinya harus dapat menghilangkan semua jenis polutan baik pencemar fisik-kimia maupun mikrobiologis. Bahan tersuspensi dapat dihilangkan dengan cara koagulasi-flokulasi, sedimentasi, filtrasi pasir atau membran filtrasi (mikrofiltrasi). Bahanbahan terlarut dapat dihilangkan dengan aerasi (misalnya $\mathrm{Fe}$ dan $\mathrm{Mn}$ ), oksidasi (misalnya dengan injeksi larutan khlorin, ozonisasi atau radiasi Ultra Violet), adsorpsi dengan karbon aktif, atau membran filtrasi (Reverse Osmosis), kesadahan dengan proses penukar ion.

Teknologi pengolahan air minum isi ulang yang dikembangkan BPPT telah diaplikasikan oleh Pemda DKI Jakarta sebagai percontohan di 11 lokasi di wilayah Jakarta Pusat menggunakan pengolahan air secara lengkap seperti terlihat pada Gambar 11

Dari hasil peninjauan lapangan seluruh depot isi ulang menggunakan dua proses pengolahan utama, yaitu Proses Filtrasi dan Sterilisasi (Lihat lampiran gambar 1 s.d. 10). Umumnya apabila air baku yang akan diolah mengandung kadar besi atau mangan terlarut cukup tinggi, maka sebelum proses filtrasi dilakukan dulu proses oksidasi. Proses oksidasi ini dilakukan dengan menginjeksi larutan kimia (kaporit atau kalium permanganat) kemudian dialirkan ke tangki reaktor.

Tetapi karena air baku yang digunakan oleh sebagian besar depot isi ulang sudah cukup baik, karena berasal dari mata air pegunungan, maka mereka tidak melakukan lagi proses oksidasi. Akan tetapi bagi sebagian kecil depot isi ulang yang menggunakan sumber air baku dari air tanah sebaiknya melakukan proses 
oksidasi untuk mengurangi kadar $\mathrm{Fe}$ dan $\mathrm{Mn}$ yang biasanya berlebih dalam air tanah.

\section{Proses Filtrasi}

Filtrasi atau penyaringan dapat dibedakan menjadi dua, yaitu filtrasi dengan pasir dan filtrasi membran. Filtrasi pasir untuk memisahkan partikel berukuran besar ( $>3$ mikrometer), mikrofiltrasi membran dapat memisahkan partikel yang berukuran lebih kecil hingga sekitar 0,08 mikrometer. Ultrafiltrasi dapat memisahkan makromolekul dan nanofiltrasi dapat memisahkan mikromolekul. Sedangkan molekul ion-ion dapat dipisahkan dengan membran dengan prinsip dasar reverse osmosis. Dengan demikian, penggunaan mikrofiltrasi dapat memisahkan bakteri, dan penggunaan ultrafiltrasi dapat memisahkan selain bakteri juga virus (ukuran virus setara dengan ukuran molekul protein, yaitu sekitar 0,02-0,1 mikrometer).

Dalam proses filtrasi, sebagian besar depot isi ulang melakukan 3 tahap filtrasi. Pertama filter berisi media pasir, kedua media mangan zeolit dan ketiga berisi media karbon aktif. Setiap filter yang berisi media ini mempunyai masing-masing fungsi. Filter pasir untuk menyaring partikel-partikel halus dari tangki air baku. Filter mangan zeolit berfungsi untuk menghilangkan zat besi atau mangan yang belum sempat teroksidasi oleh khlorin atau kaporit. Filter karbon aktif berfungsi untuk menghilangkan polutan mikro misalnya zat organik, deterjen, bau, senyawa phenol serta untuk menyerap logam berat dan lain-lain. Pada filter karbon aktif ini terjadi proses adsorpsi (proses penyerapan zat-zat yang akan dihilangkan) oleh permukaan pori-pori karbon aktif. Apabila seluruh permukaan karbon aktif sudah jenuh, atau sudah tidak mampu lagi menyerap, maka proses penyerapan akan berhenti, dan pada saat ini karbon aktif harus diganti dengan karbon aktif yang baru.

Dari 10 depot yang ada terlihat bahwa dalam proses filtrasi, terdapat 6 depot yang sudah memasang 3 filter yang berisi mediamedia seperti yang telah disebutkan diatas. Meskipun masing-masing depot tidak ada keseragaman dalam ukuran, bentuk maupun bahan filter.

Kemudian setelah itu air dialirkan ke filter cartridge. Ukuran cartridge bermacam-macam mulai dari 1 micron sampai 10 mikron dan dipergunakan untuk menghilangkan sisa partikel padatan yang ada di dalam air sehingga air menjadi benar-benar jernih.

Dari jumlah filter cartridge yang terpasang, setiap depot memasang dengan jumlah yang beragam, bahkan terlihat ada yang memasang secara berlebihan (16 cartridge terpasang seri).

\section{Proses Sterilisasi}

Proses ini untuk membunuh kuman dan bakteri. Proses sterilisasi ini dapat dilakukan dengan berbagai cara, yaitu dengan pemanasan hingga titik didih air, atau dengan khlorinasi atau dengan cara ozonisasi dan sinar ultraviolet. Cara yang paling mudah dan murah adalah dengan cara khlorinasi, yaitu mencampurkan kaporit ke dalam air.

Namun pada depot air minum isi ulang, cara yang paling banyak digunakan adalah dengan memasang lampu ultraviolet. Air dialirkan melalui tabung yang dipasang lampu ultraviolet berintensitas tinggi, sehingga bakteri terbunuh oleh radiasi sinar ultraviolet. Intensitas lampu ultraviolet yang dipakai harus cukup, yang efektif diperlukan intensitas sebesar $30.000 \mathrm{MW}$ $\mathrm{sec} / \mathrm{cm}^{2}$ (Micro Watt detik per sentimeter persegi). Proses yang relatif baru adalah mencampur gas ozon kedalam air, dikenal dengan nama ozonisasi. Ozon merupakan oksidator kuat yang mampu membunuh bakteri patogen, termasuk virus.

Keuntungan penggunaan ozon adalah pipa, peralatan, dan kemasan akan ikut disterilkan, sehingga produk yang dihasilkan akan lebih terjamin selama tidak ada kebocoran di kemasan ozon generator. Ozon merupakan bahan yang efektif disamping sangat aman. Akan tetapi karena ozon bersifat oksidator juga, maka apabila air baku yang masih mengandung $\mathrm{Fe}$ atau Mn melewati ozonisasi, maka air yang diproses akan dapat berubah menjadi sedikit berwarna kekuningan atau kecoklatan (karena terbentuknya partikel $\left.\mathrm{Fe}(\mathrm{OH})_{3}\right)$. Jadi sebaiknya air yang akan melewati proses ozonisasi harus benar-benar bersih.

Dari 10 depot isi ulang seluruhnya telah menggunakan proses sterilisasi dengan pemakaian ultraviolet, dan 5 depot telah menggunakan gabungan antara proses ozonisasi dan ultraviolet. Jenis dan merk ultraviolet yang dipasang di setiap depot tidak sama, bahkan ada yang memasang lebih dari satu unit alat.

\subsection{Sistem Pengelolaan Depot Air Isi Ulang}

Aspek pengelolaan alat ditinjau untuk mengetahui bagaimana sistem pengelolaan yang mereka laksanakan secara rutin, misalnya melakukan pencucian filter (back-wash), pencucian dan pengisian botol galon, penggantian media filter, pemeriksaan kualitas air secara berkala, biaya pemeliharaan/ perbaikan kerusakan, operator dan lain sebagainya.

Kunci dari sistem pengelolaan depot air isi ulang adalah pada kualitas operatornya. Tugas 
seorang operator adalah selain melakukan pengoperasian sistem pengolahan air, juga melakukan perawatan atau pemeliharaan secara disiplin. Tingkat pendidikan para operator pada usaha-usaha depot air isi ulang umumnya adalah setara dengan SMU. Tingkat pendidikan ini sudah cukup, namun harus sudah memperoleh paling tidak training atau pelatihan pengoperasian proses pengolahan air isi ulang. Kenyataan di lapangan adalah banyak operator yang tidak menguasai betul apa fungsi dan kharakter dari unit-unit proses dan perangkat proses pengolahan air yang ada. Mereka umumnya hanya diperintahkan menjalankan operasi dengan cara yang sangat sederhana, yaitu tekan tombol dan buka-tutup kran. Cara penguasaan pengoperasian seperti ini sungguh mengkhawatirkan, terutama bila terjadi kontaminasi terhadap air baku yang digunakan.

Karena kondisi yang seperti itu, maka pihak pemilik modal ada yang merangkai unitunit pemroses pengolahan air minum dengan over design, misalnya dengan menerapkan 16 filter cartridge yang dipasang paralel 4 jalur dan setiap terdiri dari 4 buah filter cartridge yang dipasang seri. Rangkaian seperti ini memang bagus, tetapi yang lebih penting lagi adalah cara perawatannya, misalnya pencucian filter secara berkala yang dilakukan sesuai dengan prosedur yang baku.

Satu hal yang sangat tidak baik adalah bila dilihat dari segi kebersihan ruang proses pengolahan air. Pada umumnya ruang proses yang terletak di belakang etalase tampak kotor dan berantakan. Ruang proses ini memang tersembunyi, karena ada pada bagian dalam, tetapi secara estetika hal ini tidak dapat diterima standar operasi. Bagaimana mungkin unit atau instalasi pengolah air minum terlihat kotor dan berkesan tidak teratur.

\subsection{Kualitas Air}

Berdasarkan hasil analisa laboratorium terhadap ke sepuluh contoh air yang berasal dari 10 Depot Air Isi Ulang yang disurvey, pada umumnya seluruhnya memenuhi baku mutu air minum (sesuai Permenkes tahun 2001 dan Baku Mutu SNI 01-3553/1996) salah satu hasil analisa dapat dilihat pada Tabel 2, terutama secara kimia dan fisika. Terpenuhinya syarat kualitas tersebut dapat diprediksi sebelumnya, karena air baku yang digunakan sebenarnya sudah memenuhi baku mutu secara kimia dan fisika, walaupun belum secara biologi. Dari 10 depot tersebut, terdapat 2 depot yang menggunakan sumber air baku dari air tanah dalam ( $>30$ meter). Berdasarkan pengukuran langsung pada dua lokasi tersebut diperoleh gambaran bahwa kandungan padatan terlarut total (TDS) di depot yang berlokasi di Pejaten (NIS) mencapai 324 ppm, sementara yang di Cipayung lebih rendah lagi, yaitu 213 ppm. Dua angka ini masih memenuhi standar baku mutu air minum, bahkan masih jauh dari batas yang dianjurkan $(<500$ ppm).

Dilihat dari sudut masyarakat pengguna atau konsumen, ternyata pada umumnya masyarakat konsumen tidak pernah mengeluhkan tentang kualitas air dari depot air minum isi ulang yang menjualnya. Selama ini memang hampir tidak ada keluhan dari pihak konsumen, tetapi hal itu karena konsumen sendiri juga tidak mengetahui syarat-syarat air minum yang sesuai Permenkes RI yang berlaku. Jarang sekali seorang pembeli menanyakan kualitas air minum isi ulang yang mau dibelinya dan kemudian membandingkan dengan baku mutu kualitas air minum yang berlaku.

\subsection{Persepsi Masyarakat Terhadap Depot Air Minum Isi Ulang}

Keberadaan depot-depot air minum isi ulang yang secara kuantitas melonjak sangat tinggi pada awal tahun 90-an, pada umumnya dapat diterima oleh masyarakat banyak yang juga mengkonsumsi air isi ulang tersebut baik secara langsung atau tidak. Dari hasil survey wawancara dengan masyarakat konsumen, umumnya (sebesar 68\%) melihat bahwa air minum isi ulang tersebut sangat praktis dan sudah dapat langsung diminum tanpa harus memasak lagi (Lihat grafik 12). Artinya bila membeli air tersebut, maka praktis mereka juga merasa telah menghemat pengeluaran biaya untuk keperluan energinya (listrik atau bahan bakar gas atau minyak. Di lain pihak, bagi pemroduksi air minum dalam kemasan yang umumnya bermodal jauh lebih besar, tentu saja kehadiran depot-depot air isi ulang tersebut menyebabkan persaingan perdagangan air minum semakin meningkat.

\section{KESIMPULAN DAN SARAN}

\subsection{Kesimpulan}

Berdasarkan hasil evaluasi melalui pendekatan survai terhadap pengelola/pemilik atau operator, dan pemeriksaan sistem operasional alat pada alat pengolah air siap minum atau isi ulang yang telah dibangun masyarakat maka dapat ditarik kesimpulan sebagai berikut:

- Secara manfaat terhadap masyarakat diperoleh hasil bahwa usaha air minum isi ulang memang dibutuhkan oleh masyarakat. Ada korelasi saling membutuhkan yang 
sangat besar antara usaha air minum isi ulang yang sudah beroperasi dengan pengguna/pelanggan. Misalnya masyarakat memilih air minum isi ulang selain harganya terjangkau juga lebih mudah diperoleh dalam waktu dan jarak yang lebih dekat. Kaitan selanjutnya memang juga mengarah pada penghematan biaya bahan bakar minyak, misalnya untuk memasak air.

- Berdasarkan kualitas air minum yang diproduksi terlihat bahwa secara keseluruhan memenuhi baku mutu air minum, dengan kisaran nilai TDS (Total Dissolved Solid) antara 41 ppm sampai dengan 172 ppm.

- Secara estetika performance dari segi fisik etalase untuk kegiatan usaha tersebut $90 \%$ sudah menunjukkan kebersihan dan hieginitas yang baik. Selebihnya (10\%) masih kurang memenuhi syarat kebersihan dan hieginitas. Sementara itu pada bagian dalam, yaitu sistem pengolahan air, seperti peralatan pompa-pompa, tabung filter pasir dan karbon aktif, Cartridge filter, tangkitangki air baku dan air hasil pengolahan masih tidak tertata rapi dan memberikan kesan kurang terpelihara/terawat, sehingga tampak agak kotor.

- Kualitas SDM (Sumber Daya Manusia) sebagian besar pengelola maupun operator kurang menguasai betul syarat-syarat SOP (Standard Operation Procedure) untuk pengoperasian unit usaha tersebut. Umumnya operator atau yang juga sekaligus merangkap sebagai pelayan penjualan hanya melakukan pembilasan, pengisian dan penutupan botol galon.

- Seluruh proses teknologi pengolahan air minum isi ulang yang digunakan dan jelasjelas sudah menggunakan air baku dengan kualitas yang baik (seperti air dari sumber mata air pegunungan dan air tanah dalam), menunjukkan sudah memenuhi standar alur proses pengolahan yang dibutuhkan. Dari segi urutan proses, ada beberapa pengelola yang berbeda dalam hal penempatan unit pemroses, seperti Cartridge filter, yang diletakkan sebelum tangki penampungan air hasil olahan atau sesudahnya. Bahkan penggunaan unit UV (Ultra Violet) pada beberapa pengelola terlihat berlebihan, yaitu sampai dua atau bahkan tiga kali proses.

- Dalam hal manajemen pengelolaan, secara umum usaha ini dilaksanakan dengan sistem kekeluargaan, sehingga disiplin operator atau penjual terkesan kurang profesional atau kurang cepat dan tanggap dalam pelayanan kepada pembeli atau calon pembeli. Demikian juga dalam hal pemasarannya, ternyata dari seluruh unit usaha kegiatan air minum isi ulang belum dilakukan promosi, baik melalui penyebaran brosur/selebaran ataupun spanduk.

- Dengan modal investasi antara Rp.10.000.000,- sampai Rp.40.000.000,masyarakat sudah dapat membuka usaha air siap minum atau isi ulang. Semakin banyak masyarakat dapat membangun alat ini maka program Penyediaan air minum berbasis masyarakat akan terus berlanjut.

- Tercipta suatu lapangan kerja baru sebab semakin banyak usaha air minum isi ulang semakin banyak pula masyarakat menikmati air minum dengan kualitas air minum yang memenuhi baku mutu, maka terbuka pula kesempatan tenaga kerja dengan upah yang cukup baik.

- Dilihat dari segi manfaat, memang sebagian usaha kegiatan ini sudah menunjukkan hasil seperti yang sudah diharapkan. Dijumpai pula satu kasus menarik, yaitu bahwa untuk suatu kawasan yang rata-rata kualitas air tanahnya buruk (misalnya daerah Jakarta Utara dan Barat), dimana sumber air tanahnya agak payau, ternyata keberadaan air minum isi ulang sangat berarti besar bagi masyarakat. Lainnya halnya untuk kawasan Jakarta Selatan yang ditemukan kadar besi dan mangan yang berlebih pada sumber air tanahnya, sehingga banyak masyarakat yang memenuhi kebutuhan air minum dan masaknya dengan membeli air minum isi ulang tersebut.

\subsection{Saran-saran}

- Diperlukan pelatihan untuk operator untuk meningkatkan kemampuan mengoperasikan alat, kebersihan/pemeliharaan sistem peralatan dan lingkungan, mampu mengambil keputusan dalam bertindak, meningkatkan motivasi bisnis, sehingga alat yang telah dibangun dapat dimanfaatkan semaksimal mungkin. Di setiap lokasi perlu dipasang atau diberikan Petunjuk Operasional Alat, sehingga menjadi acuan agar operator bertindak sesuai prosedur.

- Berdasarkan pengamatan langsung, terlihat bahwa proses pengolahan dari setiap usaha air siap minum/isi ulang ini sangat beragam. Karena itu dibutuhkan pula standarisasi sistem pemroses dan teknologi yang digunakan dalam pelaksanaan kegiatan pengolahan air minum isi ulang. Tentunya diperlukan suatu regulasi standar yang dikeluarkan oleh instansi yang berwenang untuk proses pengolahan air siap minum/isi ulang, agar kesehatan masyarakat lebih terjamin. 
- Untuk meningkatkan keberdayaan masyarakat dalam pemenuhan kebutuhan air bersih atau air minum, dibutuhkan suatu hubungan yang sehat antara pengelola unit air minum isi ulang dan masyarakat umum sebagai konsumen. Sedangkan untuk meningkatkan penjualan diperlukan usaha pemasaran dan manajemen usaha yang baik. Sebaliknya dari pihak masyarakat sebenarnya juga dibutuhkan masukanmasukan atau kritik membangun yang pasti sangat berguna bagi pengelola atau pengusaha air minum isi ulang tersebut. Keberdayaan masyarakat dapat ditunjukkan misalnya dengan mengetahui betul standar atau tingkat kualitas air minum yang mereka butuhkan, sehingga apabila mereka memperoleh air minum yang tidak memenuhi syarat baku mutu air minum, maka mereka segera dapat segera tergerak untuk menyampaikan keluhan atau complaint paling tidak pada unit usaha yang bersangkutan, atau bahkan mungkin ada suatu wadah tertentu untuk melindungi masyarakat sebagai konsumen.

- Mengingat bahwa usaha air minum isi ulang ini adalah industri skala kecil, jika diharuskan pemeriksaan kualitas air secara rutin sesuai dengan KepMen Kesehatan No. 907 Tahun 2002 akan sangat memberatkan. Untuk mengatasi hal tersebut pemeriksaan lengkap kualitas air dilakukan 1 tahun sekali sedangkan pemeriksaan rutin hanya untuk parameter bakteriologis (Coli) yang dilakukan setiap 3 bulan sekali. Hal ini mengingat air baku yang digunakan umumnya adalah air sumber yang berasal dari pegunungan dimana kualitasnya relatif baik dan konstan/stabil.

- Kewenangan pemeriksaan masih belum diketahui oleh pengelola secara jelas, menurut responden selama ini yang melakukan pemeriksaan adalah dari Dinas Kesehatan, akan tetapi mereka tidak pernah mendapatkan hasil analisa kualitas hasil olahan. Sebaiknya memberlakukan peraturan yang jelas bagi usaha air minum isi ulang dalam memeriksakan kualitas air minumnya secara periodik dan sebaiknya disosialisasi kepada pengusaha / pengelola.

\section{DAFTAR PUSTAKA}

1. Satmoko Yudo, Nusa Idaman Said, "Masalah Pencemaran Air Di Jakarta, Sumber dan Alternatif Penanggulangannya", Jurnal Teknologi Lingkungan, Vol. 2 No. 2, Mei, 2001. ISSN:1411-318x.

2. P. Nugro Rahardjo, "Teknologi Pengolahan Air ", Buku Pelatihan Teknologi Pengelolaan dan Pengolahan Air Bersih, Juni, 2003.

3. Tchobanoglous, G. \& Schroeder, D.Edward, "Water Quality", Addison-Wesley Publishing Company, United States of America, 1987.

4. "Water Treatment Handbook", Lavoisier Publishing, Sixth Edition, 1991.

\section{LAM PIR A N}

Tabel 1. Daftar Lokasi Alat Pengolah Air Siap Minum

\begin{tabular}{|l|l|l|l|l|l|}
\hline No. & \multicolumn{1}{|c|}{ Alamat } & \multicolumn{1}{|c|}{ Kelurahan } & \multicolumn{1}{|c|}{ Kecamatan } & \multicolumn{1}{c|}{ Wilayah } & \multicolumn{1}{|c|}{ Pemilik } \\
\hline 1. & $\begin{array}{l}\text { Jl. Johar Baru Utara III RT/RW } \\
002 / 03\end{array}$ & Johar Baru & Johar Baru & Jakarta Pusat & Bpk Rian \\
\hline 2. & $\begin{array}{l}\text { Jl. Percetakan Negara II RT/RW } \\
003 / 03\end{array}$ & Johar Baru & Johar Baru & Jakarta Pusat & Ibu Ade Ernawati \\
\hline 3. & $\begin{array}{l}\text { Jl. Marunda Tiram } \\
\text { RT/RW 002/04 }\end{array}$ & Merunda & Cilincing & Jakarta Utara & $\begin{array}{l}\text { PD SS Cab. } \\
\text { Rasban }\end{array}$ \\
\hline 4. & $\begin{array}{l}\text { Jl. Sungai Tiram } \\
\text { RT/RW 006/06 }\end{array}$ & Merunda & Cilincing & Jakarta Utara & Ayu Burhannudin \\
\hline 5. & $\begin{array}{l}\text { Jl. AMD No. 34 } \\
\text { RT/RW 003/03 }\end{array}$ & Meruya Utara & Kembangan & Jakarta Barat & Mukti Ali \\
\hline 6. & Jl. Kembang Kerep RT/RW 003/03 & Meruya Utara & Kembangan & Jakarta Barat & Ibu Ani \\
\hline 7. & $\begin{array}{l}\text { Jl. Agung Raya I } \\
\text { RT/RW 009/02 }\end{array}$ & $\begin{array}{l}\text { Lenteng } \\
\text { Agung }\end{array}$ & Jagakarsa & $\begin{array}{l}\text { Jakarta } \\
\text { Selatan }\end{array}$ & Mahdi \\
\hline 8. & $\begin{array}{l}\text { Jl. NIS - Jeruk Purut } \\
\text { RT/RW 003/03 }\end{array}$ & $\begin{array}{l}\text { Cilandak } \\
\text { Timur }\end{array}$ & Pasar Minggu & $\begin{array}{l}\text { Jakarta } \\
\text { Selatan }\end{array}$ & Subiyanto \\
\hline 9. & $\begin{array}{l}\text { Jl. Mandor Hasan/ Jl. Tengki } \\
\text { RT/RW 003/03 }\end{array}$ & Cipayung & Cipayung & Jakarta Timur & Bpk. HM. Soleh \\
\hline 10. & $\begin{array}{l}\text { Jl. Raya Hankam Cipayung } \\
\text { RT/RW 006/03 }\end{array}$ & Cipayung & Cipayung & Jakarta Timur & Bpk. Drs. Suharjo \\
\hline
\end{tabular}




\section{BEBERAPA PROSES PENGOLAHAN DEPOT AIR MINUM ISI ULANG}

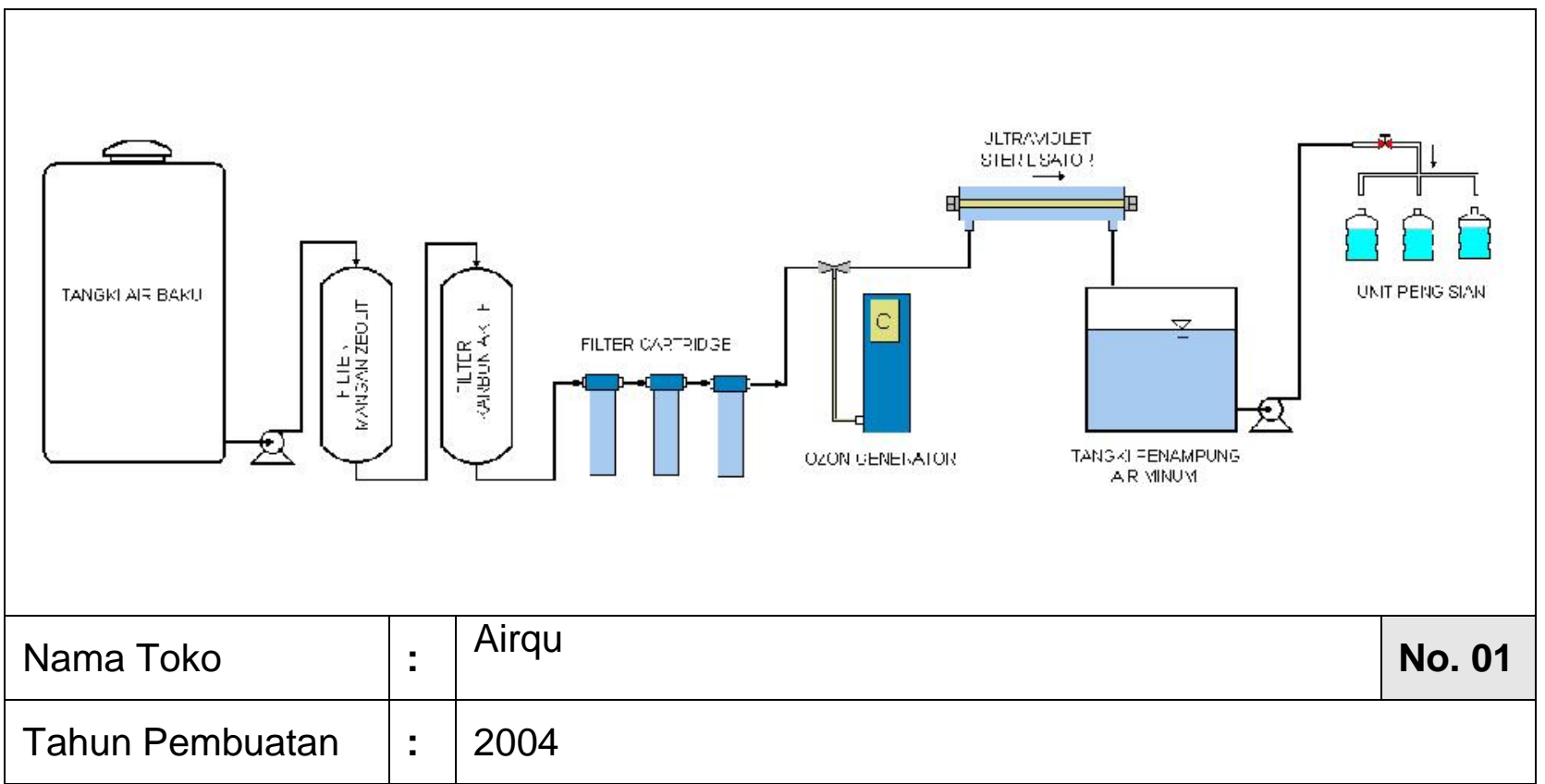

Gambar 1 : Proses Pengolahan Air Minum Isi Ulang di Jl. Percetakan Negara II RT/RW 003/03 Kel. Johar Baru, Kec. Johar Baru - Jakarta Pusat

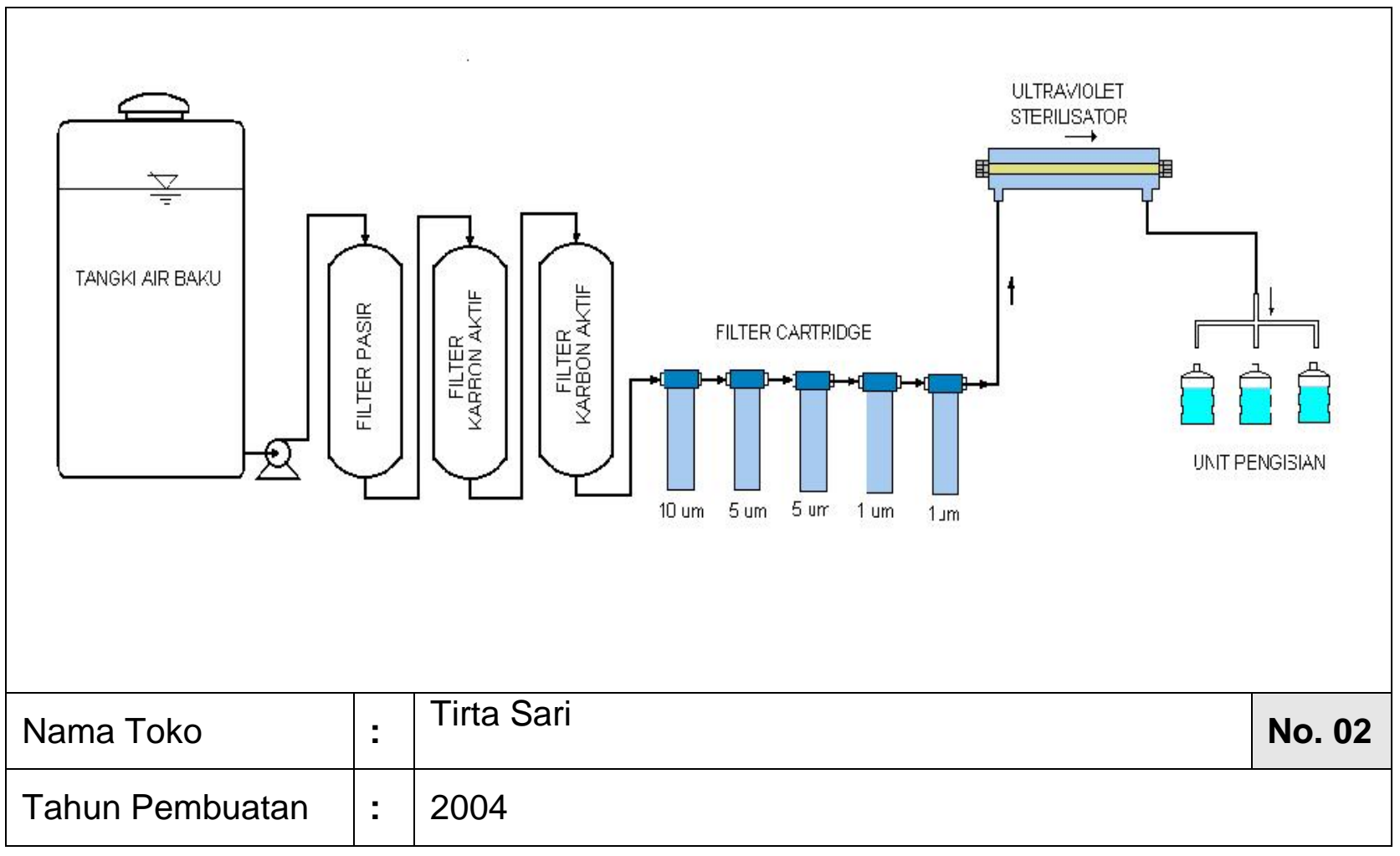

Gambar 2 : Proses Pengolahan Air Minum Isi Ulang di Jl. Johar Baru Utara III No. 20 Kel. Johar Baru, Kec. Johar Baru - Jakarta Pusat 


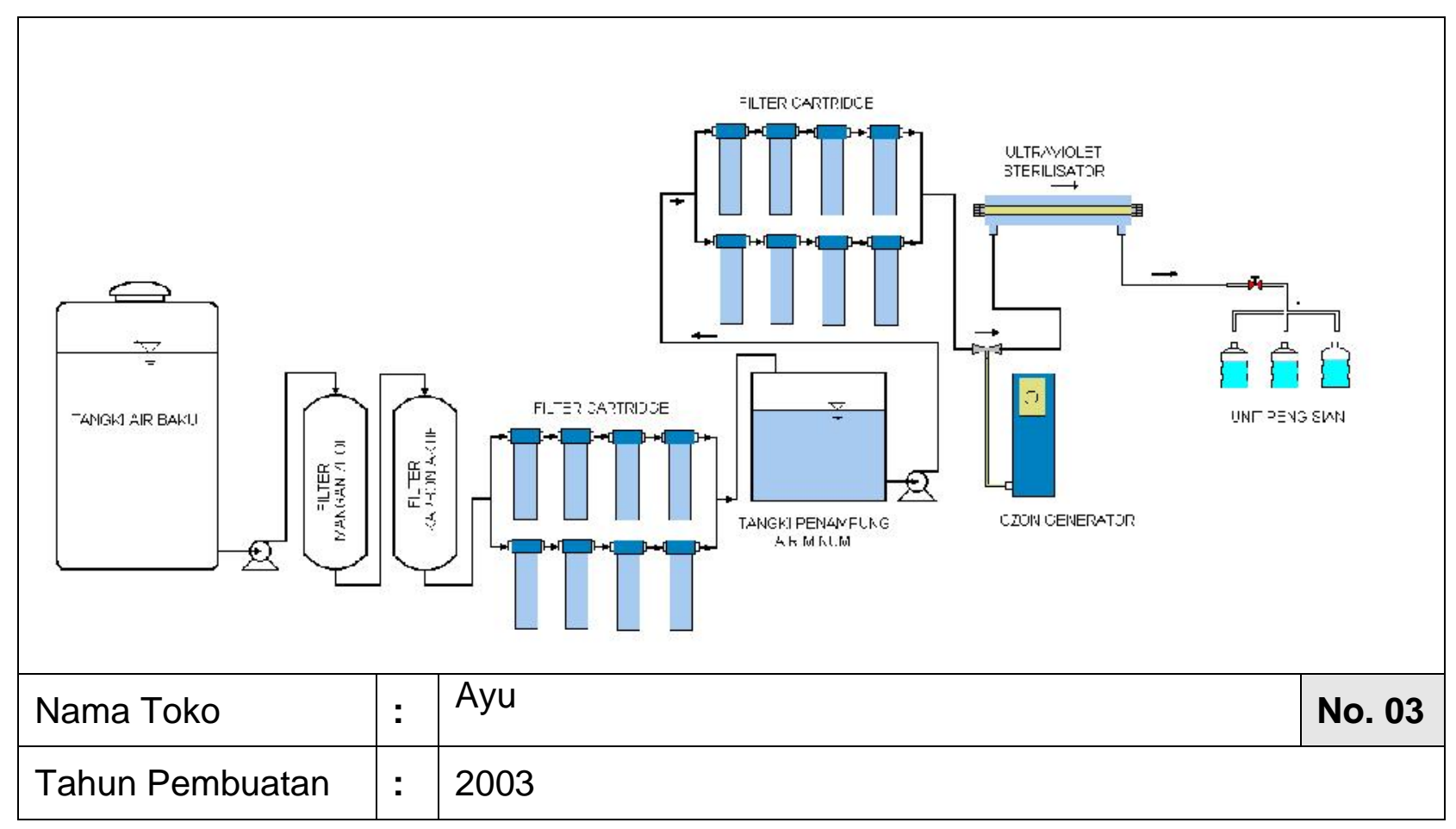

Gambar 3 : Proses Pengolahan Air Minum Isi Ulang di Jl. Sungai Tiram RT/RW 006/06 Kel. Marunda, Kec. Cilincing - Jakarta Utara

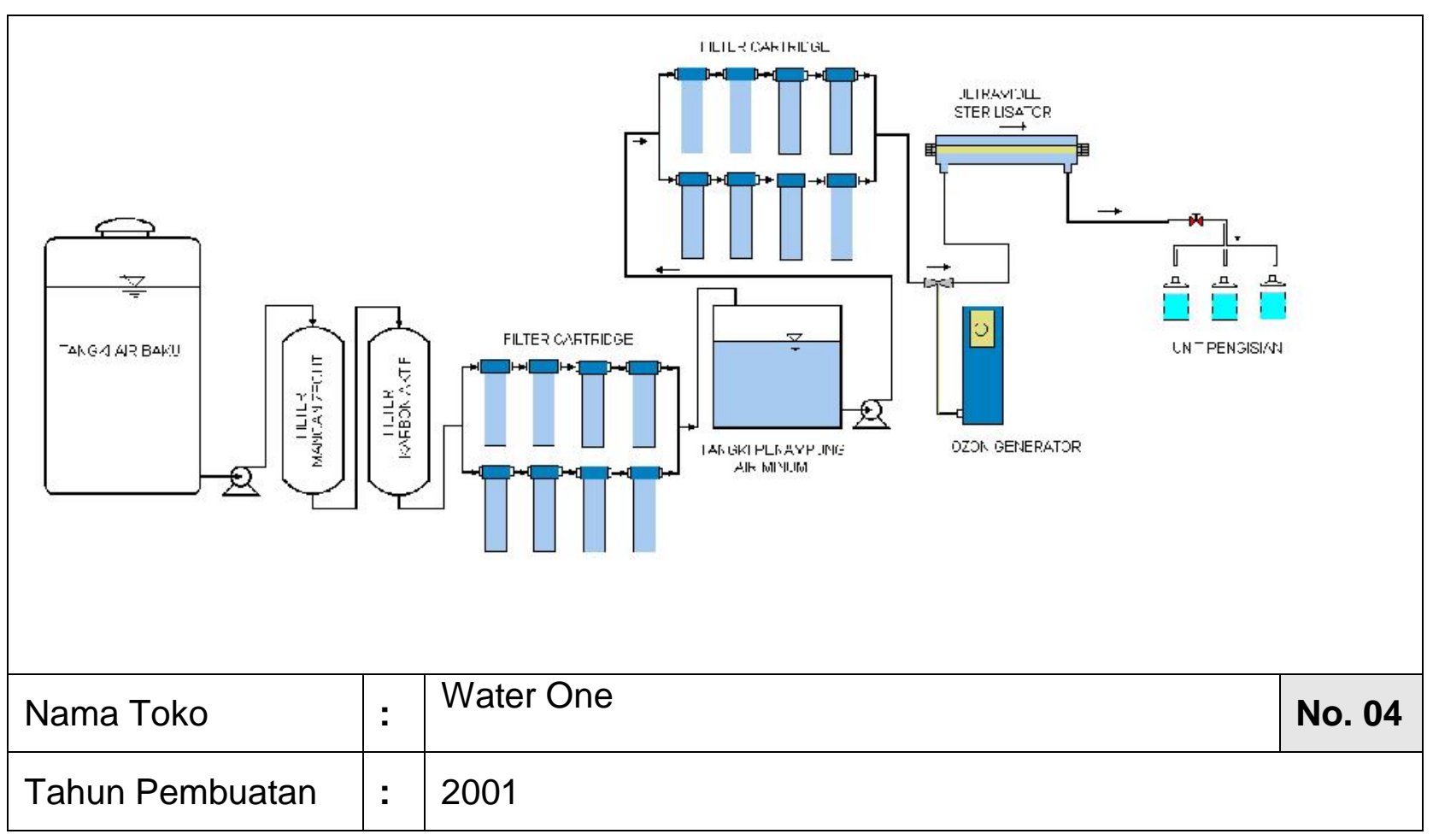

Gambar 4 : Proses Pengolahan Air Minum Isi Ulang di Jl. Sungai Marunda Tiram RT/RW 002/04 Kel. Marunda, Kec. Cilincing - Jakarta Utara 


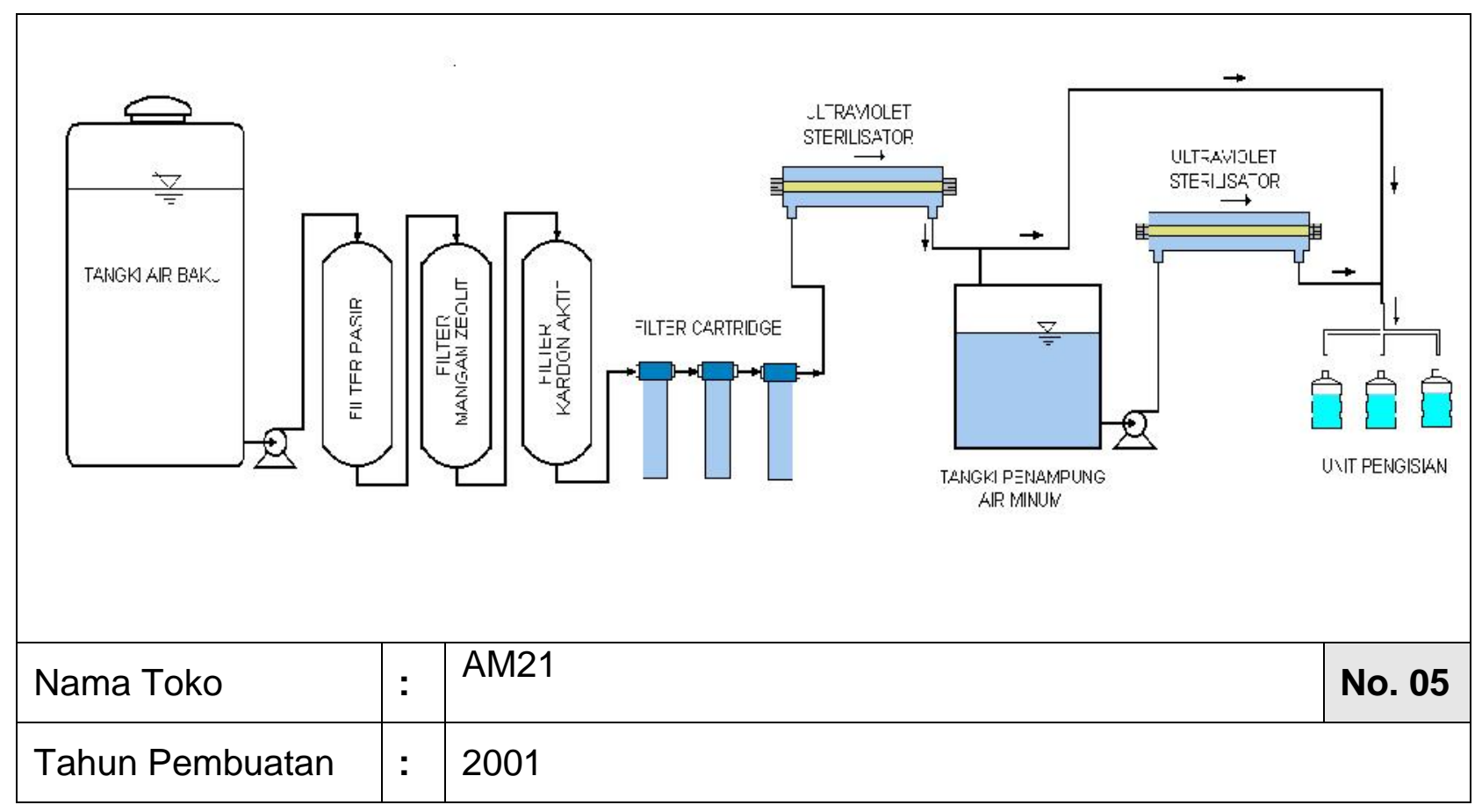

Gambar 5 : Proses Pengolahan Air Minum Isi Ulang di Jl. Kembang Kerep No. 18 RT/RW 005/06 Kel. Meruya Utara, Kec. Kembangan - Jakarta Barat

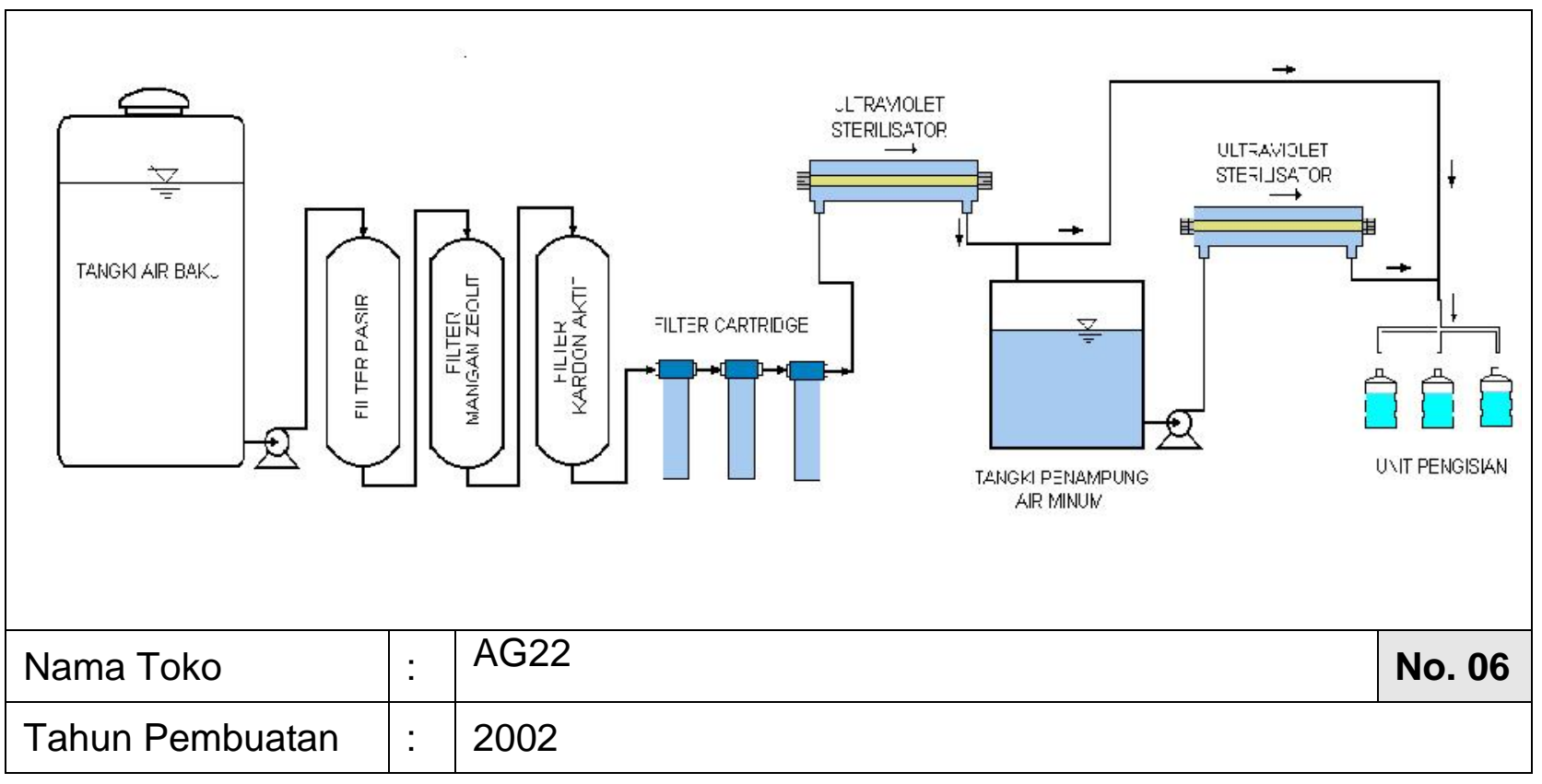

Gambar 6 : Proses Pengolahan Air Minum Isi Ulang di Jl. Kembang Kerep No. 99A RT/RW 002/02 Kel. Meruya Utara, Kec. Kembangan - Jakarta Barat 


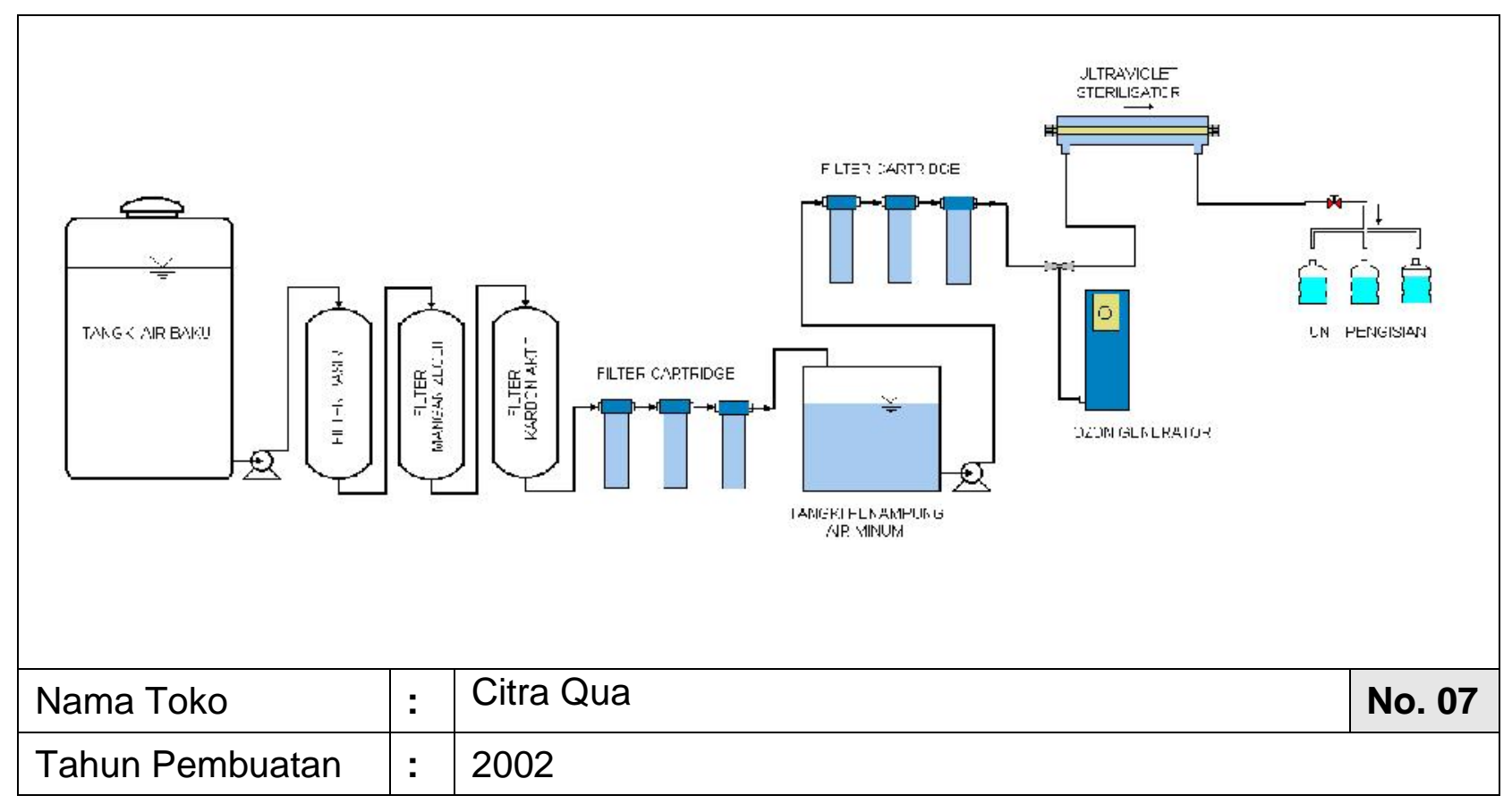

Gambar 7 : Proses Pengolahan Air Minum Isi Ulang di Jl. Mandor Hasan RT/RW 001/02 Kel. Cipayung, Kec. Cipayung - Jakarta Timur

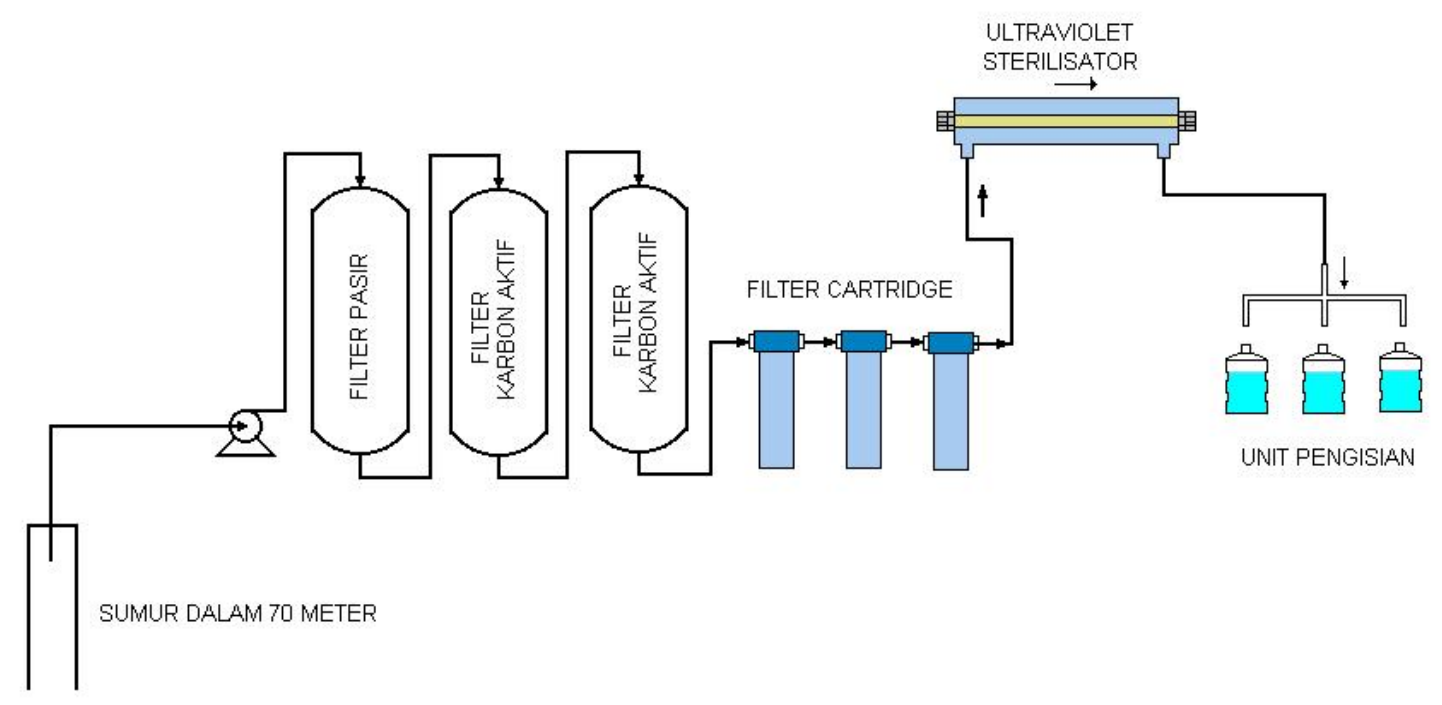

\begin{tabular}{|l|l|l|l|}
\hline Nama Toko & $:$ & Akua Fajri & No. 08 \\
\hline Tahun Pembuatan & $:$ & 2003 & \\
\hline
\end{tabular}

Gambar 8 : Proses Pengolahan Air Minum Isi Ulang di Jl. Raya Hankam No. 104A RT/RW 006/03 Kel. Cipayung, Kec. Cipayung - Jakarta Timur 


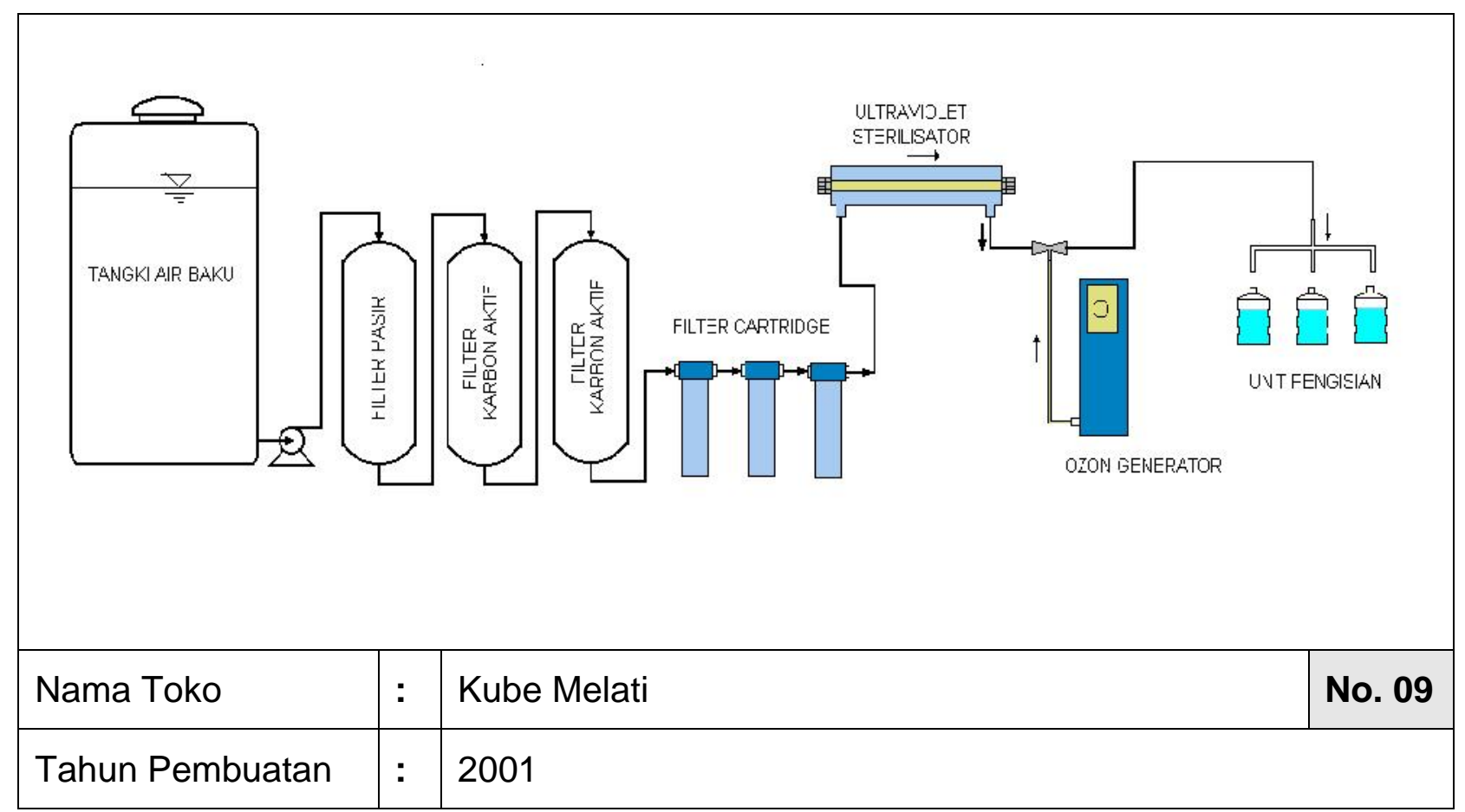

Gambar 9 : Proses Pengolahan Air Minum Isi Ulang di Jl. Agung Raya 1A No. 30 RT/RW 009/02 Kel. Lenteng Agung, Kec. Jagakarsa - Jakarta Selatan

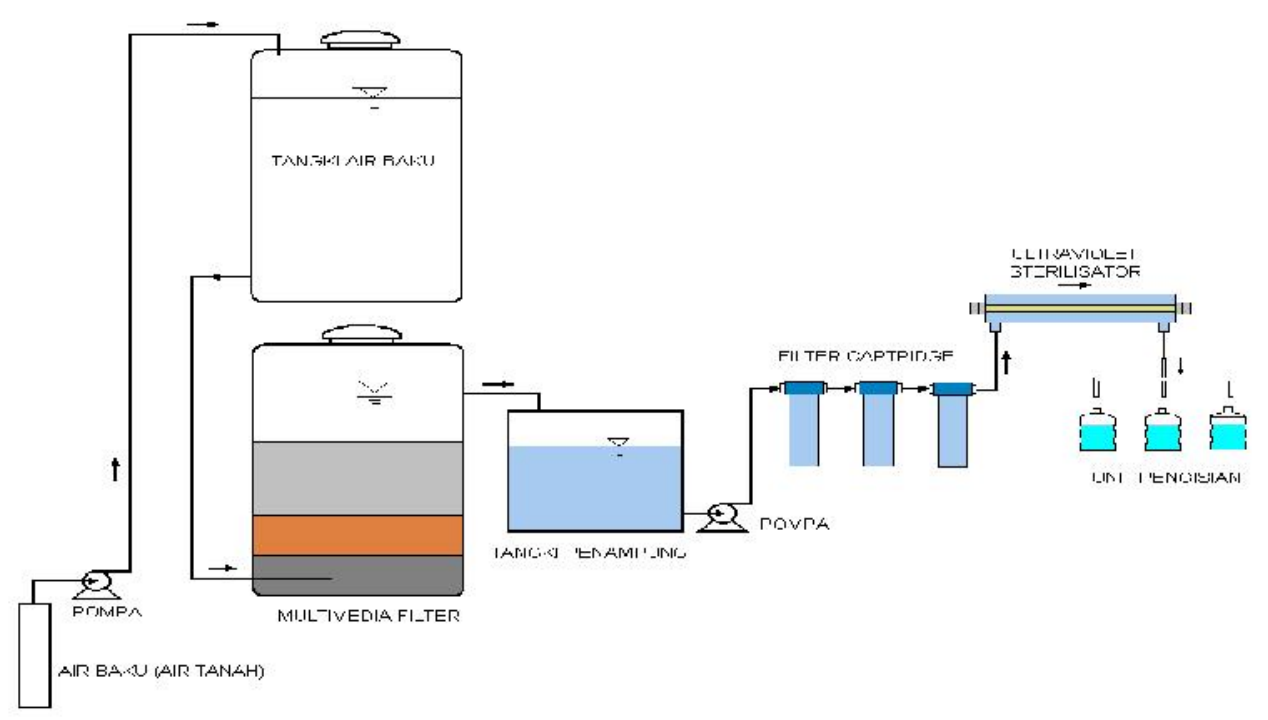

\begin{tabular}{|l|l|l|l|}
\hline Nama Toko & $:$ & Karang Taruna & No. 10 \\
\hline Tahun Pembuatan & $:$ & 2004 & \\
\hline
\end{tabular}

Gambar 10 : Proses Pengolahan Air Minum Isi Ulang di JI. NIS Jeruk Purut RT/RW 003/03 Kel.Cilandak Timur, Kec.Pasar Minggu- Jakarta Selatan 


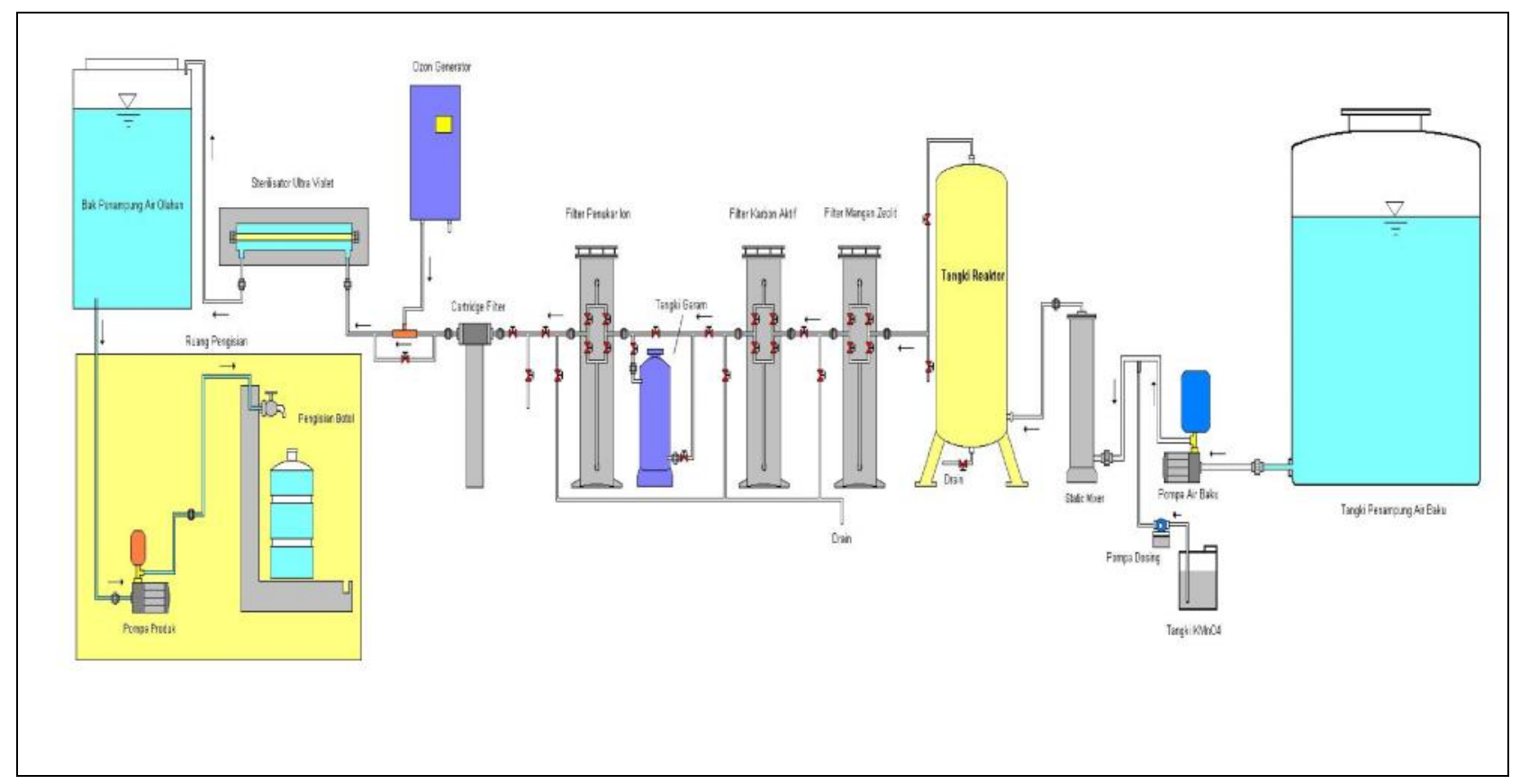

Gambar 11 : Proses Pengolahan Air Minum Isi Ulang Secara Lengkap

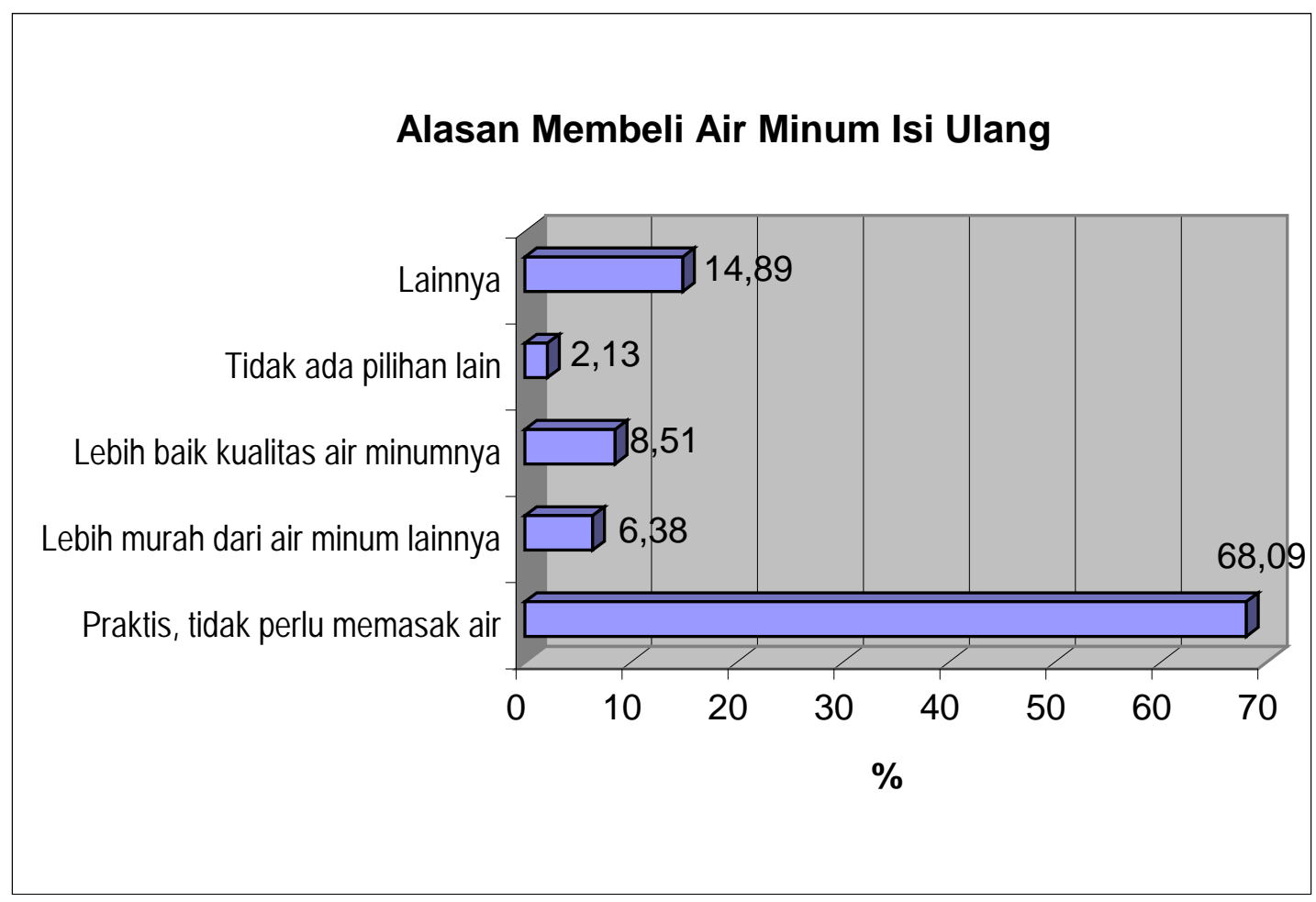

Grafik 12 : Beberapa Alasan Masyarakat Membeli Air Minum Isi Ulang 
Tabel 2 : Hasil Analisa Lab. Depot Isi Ulang milik Fadjri yang berlokasi di Jl. Hankam Cipayung, Jakarta Timur

\begin{tabular}{|c|c|c|c|c|c|}
\hline NO. & PARAMETER & SATUAN & $\begin{array}{c}\text { BAKU *) } \\
\text { MUTU }\end{array}$ & HASIL & METODE \\
\hline A. & FISIKA & & & & \\
\hline 1. & Bau & - & Tdk berbau & Tdk berbau & SNI. 01-3554-1998, butir 2.2 \\
\hline 2. & Rasa & - & Normal & Normal & SNI. 01-3554-1998, butir 2.2 \\
\hline 3. & Warna & Pt-Co & 5 & $<1$ & SNI. 01-3554-1998, butir 2.1 \\
\hline 4. & Kekeruhan & NTU & 5 & $<1$ & SNI. 01-3554-1998, butir 4 \\
\hline 5. & Zat padat terlarut (TDS) & $\mathrm{Mg} / \mathrm{l}$ & 500 & 144 & SNI. 01-3554-1998, butir 6 \\
\hline B & KIMIA & & & & \\
\hline 1. & $\mathrm{PH}(268 \mathrm{C})$ & - & $6,5-8,5$ & 7,0 & SNI. 01-3554-1998, butir 3 \\
\hline 2. & Kesadahan total (CaC03) & $\mathrm{Mg} / \mathrm{l}$ & 150 & 86,4 & SNI. 01-3554-1998, butir 5 \\
\hline 3. & Zat organik (KMn04) & $\mathrm{Mg} / \mathrm{l}$ & 1,0 & $<0,2$ & SNI. 01-3554-1998, butir 7 \\
\hline 4. & Nitrat (N03-N) & $\mathrm{Mg} / \mathrm{l}$ & 45 & $<0,1$ & SNI. 06-2480-1991 \\
\hline 5. & Nitrit (N02-N) & $\mathrm{Mg} / \mathrm{l}$ & 0,005 & $<0,002$ & SNI. 01-3554-1998, butir 9 \\
\hline 6. & Amonia (NH4) & $\mathrm{Mg} / \mathrm{l}$ & 0,15 & $<0,01$ & SNI. 01-3554-1998, butir 10 \\
\hline 7. & Sulfat (S04) & $\mathrm{Mg} / \mathrm{l}$ & 200 & 5,7 & SNI. 01-3554-1998, butir 11 \\
\hline 8. & Fluorida $(\mathrm{F})$ & $\mathrm{Mg} / \mathrm{l}$ & 250 & 14,6 & SNI. 01-3554-1998, butir 12 \\
\hline 9. & Fluorida (F) & $\mathrm{Mg} / \mathrm{l}$ & 1,0 & 0,14 & SNI. 01-3554-1998, butir 13 \\
\hline 10. & Sianida $(\mathrm{CN})$ & $\mathrm{Mg} / \mathrm{l}$ & 0,05 & $<0,005$ & SNI. 01-3554-1998, butir 14 \\
\hline 11. & Besi (Fe) & $\mathrm{Mg} / \mathrm{l}$ & 0,3 & $<0,06$ & SNI. 01-3554-1998, butir 15 \\
\hline 12. & Mangan (Mn) & $\mathrm{Mg} / \mathrm{l}$ & 0,05 & $<0,02$ & SNI. 01-3554-1998, butir 16 \\
\hline 13. & C12 bebas & $\mathrm{Mg} / \mathrm{l}$ & 0,1 & $<0,01$ & SNI. 01-3554-1998, butir 19 \\
\hline 14. & Timbal (Pb) & $\mathrm{Mg} / \mathrm{l}$ & 0,005 & $<0,005$ & SNI. 01-3554-1998, butir 17.1 \\
\hline 15. & Tembaga (Cu) & $\mathrm{Mg} / \mathrm{l}$ & 0,5 & $<0,02$ & SNI. 01-3554-1998, butir 17.2 \\
\hline 16. & Kadmium (Cd) & $\mathrm{Mg} / \mathrm{l}$ & 0,005 & $<0.003$ & SNI. 01-3554-1998, butir 17.3 \\
\hline 17. & Air Raksa $(\mathrm{Hg})$ & $\mathrm{Mg} / \mathrm{l}$ & 0,001 & $<0,0005$ & SNI. 01-3554-1998, butir 17.4 \\
\hline 18. & Arsen (as) & $\mathrm{Mg} / \mathrm{l}$ & 0,05 & $<0,005$ & SNI. 01-3554-1998, butir 18 \\
\hline C. & MIKROBIOLOGI & & & & \\
\hline 1. & Angka Lempeng Total Awal & Koloni/ml & 100 & 0 & SNI. 01-3554-1998, butir 20.1 \\
\hline 2. & Koliform & MPN/100 ml & $<2$ & $<2$ & SNI. 01-3554-1998, butir 20.2 \\
\hline 3. & C. Perfrigens & & Negatif/100ml & Negatif & SNI. 01-3554-1998, butir 20.3 \\
\hline 4. & Salmonelia & & Negatif/100 ml & Negatif & SNI. 01-3554-1998, butir 20.4 \\
\hline
\end{tabular}

\section{Kesimpulan :}

Berdasarkan hasil analisis fisika, kimia dan mikrobiologi diatas, air tersebut sudah memenuhi syarat air minum kemasan sesuai Baku Mutu SNI 01-3553/1996 